\title{
Crop year effects on seed yields, growing cycle length, and chemical composition of chia (Salvia hispanica L) growing in Ecuador and Bolivia
}

\author{
Ricardo Ayerza (h)* \\ College of Agriculture, Península de Santa Elena State University, La Libertad, Ecuador
}

\section{A B S T R A C T}

\begin{abstract}
The chia (Salvia hispanica L.), belongs to the Lamiaceae family and is an annual herb that grows in summer. The present study was conducted on seeds commercially grown in two different ecosystems called Sub-Humid Chaco, in Bolivia, and Tropical Forest, in Ecuador. The crop year effect on the growing cycle length, seed yield, seed's protein content, lipid content, and fatty acids profile, was measured during four years. The seeds from Ecuador had higher average yields at each year crop, than the seeds from Bolivia. Overall, the oil of seeds from the Tropical Forest Ecosystem showed significant $(P<0.05)$ higher content of $\alpha$-linolenic fatty acid and significant $(\mathrm{P}<0.05)$ lower $\omega-6$ : $\omega$-3 ratio than the oil of seeds from the Sub-Humid Chaco Ecosystem, and also the lowest significant $(P<0.05) \alpha$-linoleic and oleic fatty acid concentrations. Regression analysis was performed, for $\alpha$-linolenic vs. oleic and linoleic fatty acid contents. Analysis using combined data of fatty acids from all four years and from both ecosystems showed that $\alpha$-linolenic fatty acid content was negatively correlated with its precursors, oleic $\left(R^{2}=0.77, P<0.0005\right)$ and linoleic $\left(R^{2}=0.92, P<0.0005\right)$ fatty acid. Comparing both countries, the oil from chia seeds grown in Ecuador showed more stability and a significant $(\mathrm{P}<0.05)$ higher $\alpha$-linolenic fatty acid content than Bolivia.
\end{abstract}

Keywords: $\alpha$-linolenic; Fatty acids; Omega-3; Salvia hispanica; Seed production

\section{INTRODUCTION}

Chia (Salvia hispanica L.) is an annual summer herb, and a member of the Lamiaceae family. In pre-Columbian times, it was one of the basic foods of several Central American civilizations. Tenochtitlan, the capital of the ancient Aztec Empire, received 5,000-15,000tons of chia annually as a tribute from conquered nations (Codex Mendoza, 1925). Following the Spanish conquest, chia essentially disappeared for 500 years, being replaced by the crops brought from, and preferred by Europeans (Ayerza and Coates, 2005a).

Chia oil has one of the highest known concentrations of $\alpha$-linolenic fatty acid, up to $66.2 \%$ (Ayerza, 1995, 2009). Recently, chia seed has become important for human health and nutrition because its $\omega-3$ fatty acid content promotes beneficial health effects (Ayerza and Coates, 2005b; Vuksan et al., 2007).

As a botanical source, variability in chia seed composition could be expected between growing locations, and between years within a location, do to genotype and environment effects as well as genetic x environment's interaction. Although, the ecosystem effect on the biochemical composition of chia seeds has been reported (Ayerza, 1995), no study was conducted on a period of successive years. Chia is cultivated by its special seeds biochemical composition, then variability related with crop growing year effect need to be explored. The present study was conducted between 2007-2010 period, on seeds commercially grown in Bolivia and Ecuador; the crop year effect on the growing cycle length, seed yield, seed's protein content, lipid content, and fatty acids profile, was determined.

\footnotetext{
*Corresponding author:

Ricardo Ayerza (h), College of Agriculture, Península de Santa Elena State University, La Libertad, Ecuador. Current address: Barrientos 1584, (1425) Buenos Aires, Argentina. E-mail: rayerza@newcrops.org
} 


\section{MATERIALS AND METHODS}

\section{Seed samples}

This study was carried out with black spotted chia seeds commercially grown in two different ecosystems, Tropical Forest, and Sub-Humid Chaco, located in Ecuador, and Bolivia, respectively (Table 1). The black spotted seeds belong to the Tzotzol variety as was reported by Ayerza and Coates (2005b).

Within the two ecosystems where the chia was grown (Table 1), representative commercial fields were selected for sampling (Table 2). The samples were collected following the seed sample instructions of the Canadian Food Inspection Agency (2008). The samples were cleaned by hand and sent to the laboratory for analysis. The experimental design used was completely randomized, with six replications.

The fields were grown using local commercial practices, and varied in size among farms. The seeding rate was $5 \mathrm{~kg} / \mathrm{ha}$; no supplemental fertilizer was applied. Between the two chia crops, soybean and rice were grown in Bolivia and Ecuador, respectively. Row (bed) spacing in the seeded fields was $0.60 \mathrm{~m}$. Chia crops were grown under natural rainfall (Table 2). The study was carried out during four successive crop years, 2007, 2008, 2009 and 2010.

\section{Chemical analysis}

Extraction and chemical analyses of oils were performed after collection of chia seeds in each crop year.

Crude nitrogen of the chia seed samples was determined by standard micro-Kjeldahl method and then converted to protein content using a 5.71 conversion factor (AOAC, 1995).

Lipids were extracted from the samples according to the method described by Folch et al. (1957) Total lipids were then converted into fatty acid methyl esters using the IRAM 5-560II method (1982), which is equivalent to ISO 5509-1978 item 6 (ISO, 1978). Fatty acid methyl esters were separated and quantified by automated gas chromatography (Model 6890, GC; Hewlett Packard Co., Wilmington, DE, USA) equipped with flame ionization detectors and $30 \mathrm{~m}$ 9 530-lm i.d. capillary column (Model HP-FFAP Free fatty acid phase; Hewlett Packard Co., Wilmington, DE, USA). The temperatures of the oven, injector, and detector were set at 180,290 and $330{ }^{\circ} \mathrm{C}$, respectively. The fatty acid composition of each sample was determined by integrating the recorded peaks using Hewlett-Packard Chem.-Station Software. Results were expressed as percentage of total fatty acids.

\section{Statistical analysis}

A one-way analysis of variance (ANOVA) was performed for oil content, individual fatty acid content, and protein content. When the $F$ value was significant $(p<0.05)$, the Student-Newman-Keuls test was used (Cohort, 2006). Additionally, correlation and regression analysis were undertaken to develop the relationship between fatty acids (Cohort, 2006).

\section{RESULTS}

Length of growing period (defined as the planting date through the harvest date), and seed yields are presented in Table 2. The mean growing cycle length ranged from 113 days at Sub-Humid-Chaco Ecosystem to 110 days at the Tropical Forest Ecosystem.

The seed yields for each year and ecosystems are presented in Table 2. Seed yields were affected by growing year. The Tropical Forest Ecosystem had higher average yields at each year crop, than the Sub-Humid Chaco Ecosystem.

The seed protein and oil content and fatty acid composition for each crop year and ecosystem are shown in Table 3. Total protein and lipid was no significantly $(\mathrm{P}<0.05)$ different among crop years for both ecosystems, except for the seeds from Tropical Forest at year 2007. In this case the lipid content of seed from Ecuador was significantly $(\mathrm{P}<0.05)$ lower than all other crop years.

Crop year effect accounted for a larger amount of variation for seed yields but almost nothing for the biochemical composition off seed from the harvest period 2007-2010 at the Tropical Forest Ecosystem. Seeds from this ecosystem showed that with the exception of oil content and saturated palmitic fatty acid content, all other fatty acid and protein contents had no significantly $(\mathrm{P}<0.05)$ differences between crop years. Unlike, seeds from the Sub-Humid Chaco

Table 1: Ecosystems of the countries where chia was grown

\begin{tabular}{|c|c|c|c|c|c|c|c|}
\hline \multirow[t]{2}{*}{ Ecosystem } & \multirow[t]{2}{*}{ Country } & \multirow[t]{2}{*}{ Latitude } & \multirow[t]{2}{*}{ Latitude } & \multirow{2}{*}{$\begin{array}{l}\text { Elevation } \\
\text { (m) }\end{array}$} & \multicolumn{3}{|c|}{ Mean/year } \\
\hline & & & & & Temp $\left({ }^{\circ} \mathrm{C}\right)$ & Rainfall (mm) & Soil type \\
\hline Sub-Humid Chaco & Bolivia & $17^{\circ} 17^{\prime} 00^{\prime \prime} \mathrm{S}$ & 17 '00" S & 265 & 24 & 1,157 & Mollic planosols \\
\hline Tropical Forest & Ecuador & $02^{\circ} 18^{\prime} 00^{\prime \prime} \mathrm{S}$ & 18 '00" S & 129 & 25 & 2,213 & Regosol lateritic \\
\hline
\end{tabular}


Ecosystem showed significant $(\mathrm{P}<0.05)$ differences between years on unsaturated fatty acids' contents.

Over the four crop years, significant $(\mathrm{P}<0.05)$ differences in protein content between ecosystems were detected (Table 3). Sub-Humid Chaco Ecosystem seeds showed the highest protein content.

Results of the fatty acid compositional analysis by origin are presented in Table 3. Gas Chromatography analysis of the oil composition of seeds from all locations and years found the presence of $\alpha$-linolenic fatty acid, followed by linoleic, oleic, palmitic and stearic fatty acids. In addition, six more fatty acids were identified in all analyzed seed samples, myristic, arachidic, gadoleic, behenic, eracic, and lignoceric. However, as all of them were present just in

Table 2: Crop growing cycle and seed yields of chia seeds from four crop years at the Sub-Humid Chaco and Tropical Forest ecosystems

\begin{tabular}{|c|c|c|c|c|c|}
\hline \multirow[t]{2}{*}{ Ecosystem } & \multirow[t]{2}{*}{ Year } & \multicolumn{2}{|c|}{$\begin{array}{l}\text { Crop growing } \\
\text { cycle }\end{array}$} & \multicolumn{2}{|c|}{ Seed yields } \\
\hline & & $\begin{array}{l}\text { Rainfall } \\
(\mathrm{mm})\end{array}$ & $\begin{array}{l}\text { Length } \\
\text { (days) }\end{array}$ & $\begin{array}{l}\text { Average } \\
(\mathrm{kg} / \mathrm{ha})\end{array}$ & $\begin{array}{l}\text { Area }^{2} \\
\text { (ha) }\end{array}$ \\
\hline \multirow[t]{6}{*}{ Sub-Humid Chaco } & 2007 & 165 & 116 & 250 & 719 \\
\hline & 2008 & 131 & 117 & 435 & 1,180 \\
\hline & 2009 & 301 & 115 & 303 & 697 \\
\hline & 2010 & 59 & 102 & 246 & 262 \\
\hline & Average & 238 & 113 & 309 & 715 \\
\hline & $\mathrm{SD}^{1}$ & 78 & 61 & 76 & 284 \\
\hline \multirow[t]{6}{*}{ Tropical Forest } & 2007 & 55 & 110 & 313 & 76 \\
\hline & 2008 & 123 & 100 & 487 & 142 \\
\hline & 2009 & 199 & 110 & 454 & 462 \\
\hline & 2010 & 165 & 120 & 624 & 483 \\
\hline & Average & 136 & 110 & 470 & 310 \\
\hline & $\mathrm{SD}^{1}$ & 53 & 71 & 111 & 183 \\
\hline
\end{tabular}

${ }^{1}$ Standard deviation; ${ }^{2}$ Total area measured traces, those fatty acids were omitted from this report. Linoleic and $\alpha$-linolenic fatty acids together constituted about $80 \%$ of the total fatty acids.

Overall, the seed from the Tropical Forest Ecosystem showed significant $(\mathrm{P}<0.05)$ higher content of $\alpha$-linolenic fatty acid comparing to that from the Sub-Humid Chaco Ecosystem. Consequently, the seeds from this ecosystem showed the lowest significant $(\mathrm{P}<0.05)$ linoleic and oleic fatty acid concentrations. The $\omega-6: \omega-3$ ratio was significantly $(\mathrm{P}<0.05)$ lower in oils from seeds grown in Ecuador compared to that of seeds grown in Bolivia.

Regression analysis was done for $\alpha$-linolenic vs. oleic and linoleic fatty acid content. The regression coefficient $\left(\mathrm{R}^{2}\right)$ and significance $(\mathrm{P})$ levels are presented in Figs. 1 and 2. Analysis using combined data of fatty acids from all four years and from both ecosystems revealed that $\alpha$-linolenic fatty acid content was negatively correlated with its

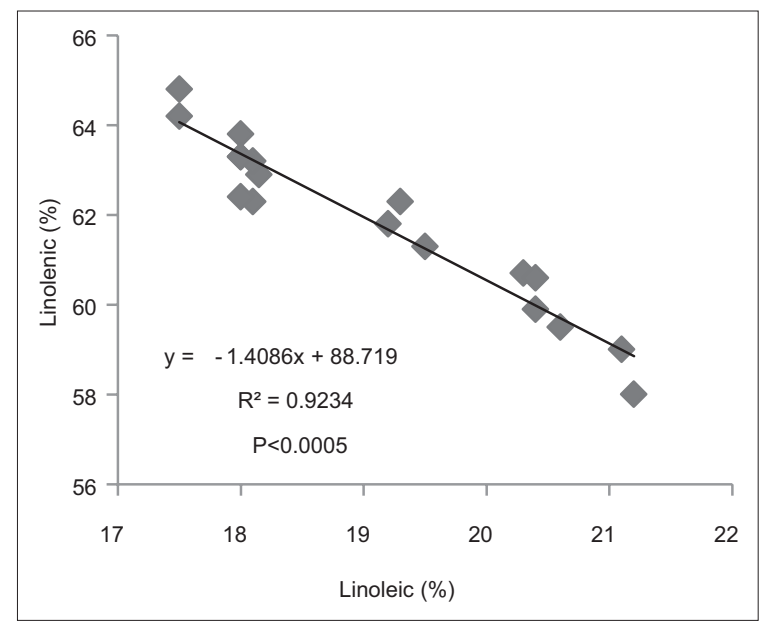

Fig 1. Relationship between $\alpha$-linolenic and oleic fatty acid contents

Table 3: Protein content, oil content and fatty acid composition of chia seeds from four crop years at the Tropical Forest (TF) and Sub-Humid Chaco (SHC) ecosystems

\begin{tabular}{|c|c|c|c|c|c|c|c|c|c|}
\hline \multicolumn{2}{|c|}{ Origin } & \multicolumn{2}{|c|}{$(\%)^{1}$} & \multicolumn{5}{|c|}{ Fatty acids $(\%)^{2}$} & \multirow{2}{*}{$\begin{array}{l}\text { Rate } \\
\omega-6: \omega-3\end{array}$} \\
\hline Ecosystem & Year & Protein & Lipids & Palmitic & Stearic & Oleic & Linoleic & $\alpha$-Linolenic & \\
\hline \multirow[t]{5}{*}{ TF } & 2007 & $18.3^{\mathrm{a} 3}$ & $27.7^{b}$ & $8.3^{a}$ & $3.3^{a}$ & $7.6^{\mathrm{a}}$ & $18.1^{\mathrm{a}}$ & $62.8^{a}$ & $0.29^{a}$ \\
\hline & 2008 & $18.7^{\mathrm{a}}$ & $33.6^{a}$ & $6.3^{b}$ & $3.6^{a}$ & $6.9^{\mathrm{a}}$ & $18.1^{\mathrm{a}}$ & $63.4^{\mathrm{a}}$ & $0.29^{a}$ \\
\hline & 2009 & $19.4^{\mathrm{a}}$ & $36.3^{a}$ & $6.9^{b}$ & $3.7^{\mathrm{a}}$ & $7.1^{\mathrm{a}}$ & $18^{\mathrm{a}}$ & $63^{a}$ & $0.29^{a}$ \\
\hline & 2010 & $19^{a}$ & $34.2^{\mathrm{a}}$ & $6.5^{\mathrm{b}}$ & $3.6^{a}$ & $6.7^{\mathrm{a}}$ & $17.6^{\mathrm{b}}$ & $64.5^{\mathrm{a}}$ & $0.27^{a}$ \\
\hline & $\mathrm{LSD}^{4}$ & 2.021 & 2.379 & 1.102 & 0.310 & 1.177 & 0.174 & 1.441 & 0.008 \\
\hline \multirow[t]{5}{*}{$\mathrm{SHC}$} & 2007 & $23.5^{\mathrm{a}}$ & $28.4^{\mathrm{a}}$ & $7^{\mathrm{a}}$ & $3.6^{\mathrm{a}}$ & $8.3^{\mathrm{a}}$ & $20.4^{\mathrm{ab}}$ & $60^{\mathrm{ab}}$ & $0.34^{\mathrm{ab}}$ \\
\hline & 2008 & $25.2^{\mathrm{a}}$ & $31.9^{a}$ & $6.7^{\mathrm{a}}$ & $3.5^{\mathrm{a}}$ & $7.2^{\mathrm{b}}$ & $19.8^{\mathrm{bc}}$ & $61.2^{\mathrm{a}}$ & $0.32^{\mathrm{b}}$ \\
\hline & 2009 & $24^{\mathrm{a}}$ & $36.1^{\mathrm{a}}$ & $7.1^{\mathrm{a}}$ & $3.5^{\mathrm{a}}$ & $7.4^{\mathrm{b}}$ & $19.4^{c}$ & $61.8^{a}$ & $0.31^{b}$ \\
\hline & 2010 & $23.1^{\mathrm{a}}$ & $32.5^{\mathrm{a}}$ & $6.3^{\mathrm{a}}$ & $4^{a}$ & $8.9^{\mathrm{a}}$ & $21.2^{\mathrm{a}}$ & $58.5^{\mathrm{b}}$ & $0.36^{a}$ \\
\hline & LSD & 4.201 & 6.314 & 1.124 & 0.422 & 1.122 & 1.023 & 1.805 & 0.025 \\
\hline \multirow[t]{3}{*}{ Overall } & TF & $18.9^{b}$ & $33.3^{a}$ & $6.9^{\mathrm{a}}$ & $3.6^{\mathrm{a}}$ & $7.1^{\mathrm{b}}$ & $17.9^{b}$ & $63.4^{a}$ & $0.29^{b}$ \\
\hline & $\mathrm{SHC}$ & $23.9^{a}$ & $31.8^{a}$ & $6.8^{\mathrm{a}}$ & $3.6^{a}$ & $7.9^{\mathrm{a}}$ & $20.2^{\mathrm{a}}$ & $60.3^{b}$ & $0.33^{a}$ \\
\hline & LSD & 1.193 & 3.525 & 0.687 & 0.219 & 0.671 & 0.550 & 1.132 & 0.015 \\
\hline
\end{tabular}

${ }^{1}$ Percentage of dry matter; ${ }^{2}$ Percentage of total fatty acids; ${ }^{3}$ Means in a column within a group with the same letter are not statistically different (P<0.05); ${ }^{4}$ Least significant difference for $\mathrm{P}<0.05$ according to Student-Newman-Keuls test 


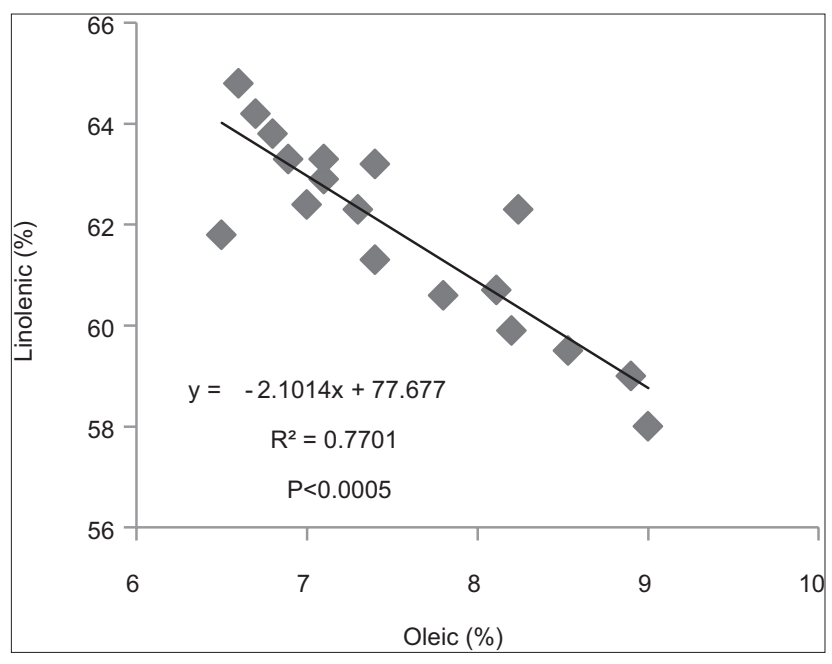

Fig 2. Relationship between $\alpha$-linolenic and linoleic fatty acid contents

precursors -oleic $\left(\mathrm{R}^{2}=0.77, \mathrm{P}<0.0005\right)$, and linoleic $\left(\mathrm{R}^{2}=0.92, \mathrm{P}<0.0005\right)$ fatty acids.

\section{DISCUSSION}

The growing cycle lengths found herein are in the range of 100-150-d reported by Ayerza (2009) for five different ecosystems that include the Tropical Forest and Sub-Humid Chaco with 100 and 120 days, respectively. However, these five ecosystems were just measured in only one crop year.

The average seed yields measured herein were lower than those reported in other experiments where yields of 1,355, 938 and $862 \mathrm{~kg} / \mathrm{ha}$ were reported for three other experimental fields. The first two were in the Sub-Humid Chaco Ecosystem and the other, which was irrigated, was in the Semiarid Chaco Ecosystem (Coates and Ayerza, 1996). Additionally, yields were less than the 1,602 and $1,188 \mathrm{~kg} / \mathrm{ha}$, for commercially irrigate fields established in two locations in the Semiarid Chaco Ecosystem (Coates and Ayerza, 1998).

Differences in seed yields between these results and earlier trials could be a result of a combination of factors including genetics, environmental conditions, agronomic practices, seeding dates and their interactions as it was demonstrated by Ayerza (2009).

Seeds produced in the Tropical Forest Ecosystem with a very low precipitation through chia growing cycles (Table 2), suggested a very good soil capacity to storage water during the rainfall season.

Generally, the fatty acid profiles of seeds from both locations are conforming to the pattern described in literature for chia, with the proportions of different fatty acids fitting within the reported ranges (Ayerza, 1995, 2009, 2010).
As it was early reported, unsaturated fatty acid contents of chia seeds are affected by environmental factors (Ayerza, 1995, 2009, 2011), then difference in biochemical composition between growing seasons within a site could be attributed to different climatic behavior between crop years.

The almost significant $(\mathrm{P}<0.05)$ no difference on polyunsaturated fatty acids between years within the Tropical Forest Ecosystem, suggests a more stable weather behavior in the Tropical Forest Ecosystem than in the SubHumid Chaco Ecosystem.

The results presented herein support the contention that ecosystem has a strong effect on protein and unsaturated fatty acids content of chia seeds (Ayerza, 2009). This has been reported for many other crops, also (Mohammed et al., 1987; Vollmann et al., 2007).

The significant negative relationship of $\alpha$-linolenic fatty acid content with the two more saturated 18-C fatty acids, oleic and linoleic, are in agreement with previous observations reported for chia oil (Ayerza, 2009). In addition, this relation has been described for a number of crops, as almonds (Abdallah et al., 1998), chestnuts (Pires Borges et al., 2007), soybeans (Thomas et al., 2003) and flaxseed which is a rich source of $\alpha$-linolenic fatty acid (Wakjira et al., 2004). This strong inverse association found herein is supported by the fact that the biosynthesis of $\alpha$-linolenic fatty acid through the process of desaturation of oleic fatty acid, via linoleic fatty acid by the action of specific desaturase enzymes (Dybing and Zimmerman, 1966).

Dietary $\omega-6$ and $\omega-3$ fatty acid relation has been identified as a risk factor of suffering a coronary heart disease, and a way of lowering the risk is to keep dietary $\omega-6: \omega-3$ fatty acid ratio as low as possible, the ratio of 1:1 being ideal (Simopulous, 2003). Western diets do not provide these ratios, mainly due to their high $\omega-6$ fatty acid content. As a $\omega-3$ source, chia is consumed either as oil or as whole/ ground seed (Ayerza and Coates, 2005a). The significant $(\mathrm{P}<0.05)$ lower $\omega-6: \omega-3$ rate (up to $13.8 \%$ ), showed by the oil from seeds grown at the Ecuador location, compared to Bolivia location, could indicate an added health benefit for those seeds.

\section{CONCLUSIONS}

In summary, the results of the present research showed that crop yields, length growing cycles, and chemical composition of chia seeds, are affected by both the ecosystem's characteristics and the crop year. However, 
compared to chia seeds grown in Bolivia, the chia seeds grown in Ecuador showed more stability and a significant $(\mathrm{P}<0.05)$ higher $\alpha$-linolenic fatty acid content. This suggests that Ecuador can be a reliable source of this fatty acid but additional multi location and multiyear trials using a larger number of genotypes, and planted under a wider range of field conditions are required to confirm and fully assess the potential of chia as crop in these two tropical ecosystems.

\section{REFERENCES}

Abdallah, A., M. H. Ahumada and T. M. Gradzie. 1998. Oil content and fatty acid composition of almond kernels from different genotypes and California production regions. J. Am. Soc. Hortic. Sci. 123: 1029-1033.

AOAC. 1995. Micro-Kjeldahl Method. Official Methods of Analysis (960.52). Association of Official Analytical Chemists, Gaithersberg, MD, USA.

Ayerza, R. (h). 1995. Oil content and fatty acid composition of chia (Salvia hispanica L.) from five northwestern locations in Argentina. J. Am. Oil Chem. Soc. 72: 1079-1081.

Ayerza, R. (h). 2009. The seed's protein and oil content, fatty acid composition, and growing cycle length of a single genotype of chia (Salvia hispanica L.) as affected by environmental factors. J. Oleo Sci. 58: 347-354.

Ayerza, R. (h). 2010. Effects of seed color and growing locations on fatty acid content and composition of two chia (Salvia hispanica L.) genotypes. J. Am. Oil Chem. Soc. 10: 1161-1165.

Ayerza, R. (h). 2011. The seed's oil content and fatty acid composition of chia (Salvia hispanica L.) variety Iztac 1, grown under six tropical ecosystems conditions. Interciencia. 8: 620-624.

Ayerza, R. (h). and W. Coates. 2005a. Chia: Rediscovering a Forgotten Crop of the Aztecs. The University of Arizona Press. Tucson, AZ.

Ayerza, R. (h). and W. Coates. 2005b. Effect of ground chia seed and chia oil on plasma total cholesterol, LDL, HDL, triglyceride content, and fatty acid composition when fed to rats. Nutr. Res. 11: 995-1003.

Canadian Food Inspection. 2008. Seed Program Specific Work Instruction: Official Seed Sampling. SWI 132.1.1, Plant Production Division, Plant Products Directorate, Government of Canada, Ottawa, Ontario, Canada.
Coates, W. and R. Ayerza. (h). 1996. Production potential of chia in Northwestern Argentina. Ind. Crop Prod. 3: 229-233.

Coates, W. and R. Ayerza. (h). 1998. Commercial production of chia in Northwestern Argentina. J. Am. Oil Chem. Soc. 10: 1417-1420.

Mendoza, C. 1925. Edition of Francisco del Paso y Troncoso. México D.F., México. Museo Nacional de Arqueología, Historia y Etnografía (in Spanish).

Cohort Stat. 2006. Cohort Stat 6.311. Cohort Software Inc., Monterey, CA.

Folch, J., M. Lees and G. H. A. Sloane-Stanley. 1957. A simple method for the isolation and purification of total lipids from tissues. J. Biol. Chem. 226: 497507.

IRAM-National Institute for Standarization. 1982. Animal and vegetable fats and oils. 1982. Preparation of methyl esters of fatty acids. Argentine Institute of Standarization, Buenos Aires, Argentina (in Spanish).

ISO. 1978. ISO 5509: Animal and vegetable fats and oils. Preparation of methyl esters of fatty acids. International Organization for Standardization. Geneva, Switzerland.

Mohammed, C. A., J. F. Francis, J. Rajewski and J. W. Maranville. 1987. Genotype H environment interaction and stability analysis of protein and oil in grain sorghum. Crop Sci. 27: 169-171.

Pires Borges, O., J. Soeiro-Carvalho, P. Reis-Correia and A. P. Silva. 2007. Lipid and fatty acid profiles of Castanea Sativa mill, chestnuts of 17 native Portuguese cultivars. J. Food Comp. Anal. 20: 80-89.

Simopoulos, A. P. 2003. Common statement. In: De Meester, F., (Ed.), First International Congress on the Columbus Concept, Belovo S.A., Bastogne, Belgium, Pp. 157-178.

Thomas, J. M. G., K. Boote, H. Allen, M. Jr. Gallo-Meagher and J. M. Davis. 2003. Elevated temperature and carbon dioxide effects on soybean seed composition and transcript abundance. Crop Sci. 43: 1548-1557.

Vollmann, J., T. Moritz, C. Karg, S. Baumgartner and H. Wagentristl. 2007. Agronomic evaluation of Camelina genotypes selected for seed quality characteristics. Ind. Crop Prod. 3: 270-277.

Vuksan, V., D. Whitham, J. L. Sievenpiper, A. L. Jenkins, A. L. Rogovik, R. P. Bazinet, E. Vidgen and A. Hanna. 2007. Supplementation of conventional therapy with the novel grain salba (Salvia hispanica L.) improves major and emerging cardiovascular risk factors in type 2 diabetes. Diabetes Care. 11: 2011-2804.

Wakjira, A., M. T. Labuschagne and A. Hugo. 2004. Variability in oil content and fatty acid composition of Ethiopian and introduced cultivars of linseed. J. Sci. Food Agric. 84: 601-607. 